\title{
MODEL PERLINDUNGAN DAN PEMENUHAN HAK PASIEN TERHADAP PELAKSANAAN INFORMED CONSENT DI INDONESIA
}

\author{
Syafruddin* dan Arif Rohman**
}

\author{
Dosen Fakultas Hukum Universitas Borneo Tarakan \\ Jalan Amal Lama Nomor 1 Tarakan, Kalimantan Utara
}

\begin{abstract}
One of an important elements that influences health law dynamics is informed consent. Although the action of doctor is protected, instead practically there are many deviations against rights for patients. This study focuses on assessment of judges about expressed consent and patient protection models on the informed consent implementation in Indonesia. Court decisions are outlined and analyzed with existing regulations, so the result described judge's assessment about expressed consent and implementation model of informed consent. The result of this study shows that judges'valuation is absolute, where they must assess expressed consent as an action to be taken by the medical, except in emergency conditions, thus patient approval is not necessity due to the agrotisalus lex suprema principle, namely patient safety is the highest law. Meanwhile, the model of protection for patients in the trial is applying reverse proof, because the medical profession is able to explain medical actions.
\end{abstract}

Keywords: Protection model, Rights for Patients, Informed Consent.

\section{Intisari}

Unsur penting yang mempengaruhi dinamika hukum bidang kesehatan salah satunya adalah informed consent. Meskipun tindakan dokter dilindungi, tetapi dalam praktik masih banyak terjadi penyimpangan terhadap hak-hak pasien. Penelitian ini fokus pada penilaian hakim atas exspressed consent dan model perlindungan pasien dalam pelaksanaan informed consent di Indonesia. Type penelitian ini adalah penelitian hukum normatif dengan pendekatan statute approach dan case approach. Putusan pengadilan diuraikan dan dianalisis dengan peraturan yang ada, sehingga hasil analisis menggambarkan penilaian hakim terhadap exspressed consent dan model pelaksanaan informed consent. Hasil penelitian menggambarkan bahwa penilaian hakim bersifat mendasar (absolut), yakni hakim harus menilai expressed consent sebagai syarat tindakan yang akan dilakukan oleh medis, kecuali dalam kondisi emergency maka persetujuan pasien tidak dibutuhkan karena menganut asas Agrotis Salus Lex Suprema yakni keselamatan pasien adalah hukum yang tertinggi. Namun, model perlindungan bagi pasien dalam persidangan adalah menerapkan pembuktian terbalik, karena profesi kedokteran yang mampu menjelaskan tindakan medik.

Kata kunci: Model, Perlindungan Pasien, Informed consent.

\section{Pokok Muatan}

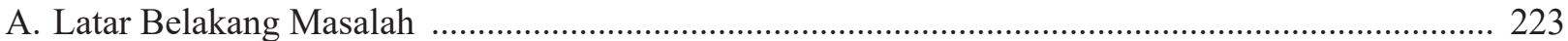

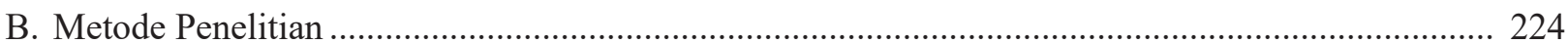

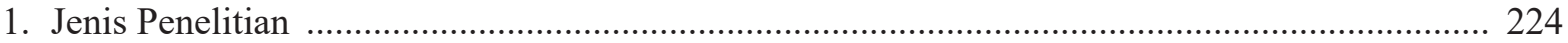

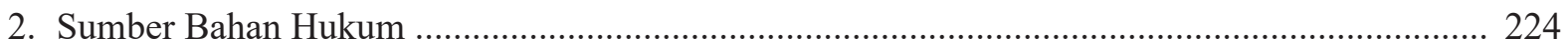

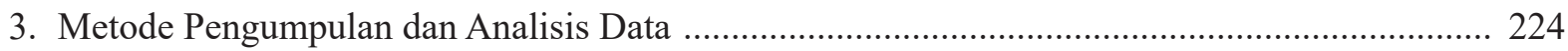

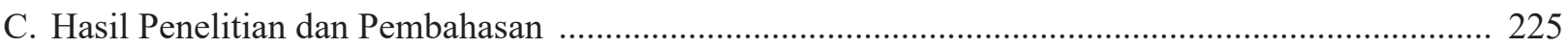

1. Penilaian Hakim Atas Expressed Consent Pada Pelaksanaan Informed Consent ........................ 225

2. Model Perlindungan Dan Pemenuhan Hak Pasien (Informed Consent) di Indonesia ................. 229

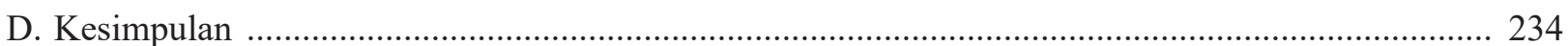

Alamat korespondensi: syaftrk2013@gmail.com.

** Alamat korespondensi: arifrohman_ubt@yahoo.com. 


\section{A. Latar Belakang Masalah}

Malpraktik di Indonesia bukan merupakan hal yang baru, tetapi kejadian ini masih saja terus berlangsung meskipun perangkat hukum yang berlaku di Indonesia sejalan dengan kebutuhan masyarakat selaku costumer jasa kesehatan. Beberapa kasus indikasi malpraktik di Indonesia dapat dijumpai di berbagai media massa, tetapi tidak semua kasus diajukan ke permukaan hukum. Adapun kasus-kasus malpraktik yang pernah terjadi yaitu antara lain adalah kasus pasien Anna Marlina versi RS Persahabatan terjadi pada tahun 2013르, kasus bayi RFB di Bekasi yang meninggal dunia diduga akibat kelalaian Tim Medis Rumah Sakit Awal Bros, tarjadi pada tahun 2015. ${ }^{2}$ Kasus bocah lumpuh di Kediri diduga terjadi setelah mendapatkan imunisasi, LPA setiap tindakan medis seperti imunisasi agar mendapat persetujuan orang tua meskipun berasal dari luar kota. Terutama untuk menanyakan kondisi sang anak sebelum mendapat perlakuan imunisasi. ${ }^{3}$

Sementara itu, pihak Majelis Kehormatan Disiplin Kedokteran Indonesia atau yang disingkat menjadi MKDKI menganggap bahwa tindakan yang dilakukan oleh dokter selama ini hanya sebatas pada dugaan pelanggaran disiplin. Hingga Maret 2011, MKDKI telah menangani 127 pengaduan kasus pelanggaran disiplin yang dilakukan dokter atau dokter gigi. Dari angka tersebut, sekitar 80 persen disebabkan kurangnya komunikasi antara dokter dan pasien. Dirinci berdasarkan disiplin ilmu yang diadukan, yang paling banyak adalah dokter umum (48 kasus), dokter ahli bedah (33 kasus), dokter ahli kandungan dan kebidanan (20 kasus), dokter ahli anak (11 kasus), dokter ahli penyakit dalam (10 kasus), dokter ahli paru (4 kasus), dokter ahli syaraf (4 kasus), dokter ahli anestesi (4 kasus), dokter ahli mata (3 kasus), dokter ahli jantung (3 kasus), dokter ahli radiologi ( 2 kasus), dan masing-masing 1 kasus oleh dokter ahli jiwa, ahli THT dan ahli kulit dan kelamin serta 10 dokter gigi. ${ }^{4}$

Berdasarkan sumber pengaduan, kasus terbanyak disampaikan oleh masyarakat yaitu 119 kasus, disusul oleh Kementerian Kesehatan/Dinas Kesehatan 4 kasus, tenaga kesehatan 2 kasus, dan masing-masing 1 kasus pengaduan dari institusi pelayanan kesehatan dan pihak asuransi. Lebih lanjut Sabir Alwy mengatakan bahwa keterampilan dokter dalam menyampaikan informasi menjadi kunci dalam situasi semacam ini. Dokter tidak cakap berkomunikasi, maka yang terjadi adalah kesalahpahaman yang berbuntut pada pengaduan oleh pasien baik ke MKDKI ataupun langsung ke aparat hukum. Ini artinya bahwa adanya kode etik kedokteran merupakan salah satu upaya non-penal bagi profesi kedokteran dalam menjalankan praktik kedokteran. Upaya tersebut menunjukkan adanya perlindungan rekan kerja (profesi) sangat penting yang didasarkan pada keilmuan. Hal ini tidak cukup bagi masyarakat selaku konsumen kesehatan, sehingga perlu adanya perangkat hukum sebagai legitimasi pasien dalam memenuhi kebutuhan dasar.

Adapun beberapa kasus yang pernah masuk ke ranah hukum dan ditangani oleh pengadilan terkait dengan malpraktik kedokteran adalah Putusan Nomor 46 K/Pdt/2006, Putusan Nomor 90/Pid.B/2011/PN Mdo, dan Putusan Nomor 1110 $\mathrm{K} / \mathrm{Pid}$.Sus/2012. Beberapa kasus ini merupakan representatif terhadap pelaksanaan penegakan hukum bidang kesehatan yang ada di Indonesia. Fokus penelitian ini bertumpu pada 2 (dua) hal, yakni Pertama, bagaimana penilaian hakim atas expressed consent pada pelaksanaan informed consent dan Kedua, bagaimana model perlindungan

Kronologi Kasus Pasien Anna Marlina versi RS Harapan, https://news.detik.com/berita/d-2229037/kronologi-kasus-pasien-anna-marlinaversi-rs-persahabatan, diakses 16 Juli 2019.

RS Awal Bros Ternyata tak berikan Resume Medis Bayi RFB, https://www.republika.co.id/berita/nasional/jabodetabek-nasional/15/12/04/ nyu64h349-rs-awal-bros-ternyata-tak-berikan-resume-medis-bayi-frb, dikases 16 Juli 2019.

Kasus Bocah Lumpuh: LPA sebut informed consent sangatlah penting, https://radarkediri.jawapos.com/read/2018/11/10/102934/kasusbocah-lumpuh-lpa-sebut-informed-consent-sangatlah-penting, diakses 16 Jui 2019.

4 Dugaan Pelanggaran Disiplin Terbanyak Akibat Kurangnya Komunikasi Dokter dan Pasien, http://www.depkes.go.id/article/view/1519/ dugaan-pelanggaran-disiplin-terbanyak-akibat-kurangnya-komunikasi-dokter-dan-pasien.html, diakses 16 Juli 2019. 
pasien dalam pelaksanan informed consent di Indonesia.

\section{B. Metode Penelitian \\ 1. Jenis Penelitian}

Penelitian ini merupakan penelitian hukum normatif, yakni mengkaji penerapan kaidah atau norma dalam hukum positif. ${ }^{5}$ Penelitian normatif juga dikenal dengan sebutan doctrinal, yakni memberikan penjelasan sistematis aturan yang mengatur hukum tertentu, menganalisis hubungan antara peraturan, dan memprediksi pembangunan masa depan. ${ }^{6}$ Penelitian ini merupakan penelitian normatif karena dasar dan acuan utama adalah peraturan perundang-undangan, seperti UndangUndang Kesehatan, Undang-Undang Praktik Kedokteran, Peraturan Menteri Kesehatan, Kitab Undang-Undang Hukum Pidana, dan Kitab Undang-Undang Hukum Acara Pidana. Pendekatan yang digunakan adalah: ${ }^{7}$

a. Pendekatan perundang-undangan (statute approach), pendekatan yang dilakukan dengan menelaah semua undang-undang dan regulasi yang berkaitan dengan isu hukum yang ditangani dalam penelitian ini adalah informed consent.

b. Pendekatan konseptual (conceptual approach), sudut pandangan praktis dan sudut pengetahuan dalam pikiran dan atribut-atribut tertentu dengan menggabungkan kata-kata dengan objek tertentu.

c. Pendekatan kasus (case approach), pendekatan yang dilakukan dengan cara melakukan telaah terhadap kasuskasus yang berkaitan dengan isu yang dihadapi yang telah menjadi putusan pengadilan yang telah mempunyai kekuatan hukum yang tetap.

Pendekatan tersebut penulis gunakan untuk menelaah dan memadukan aturan hukum tentang informed consent dengan kasus yang terjadi selama ini dengan melihat konsep pemenuhan hak pasien sebagai bentuk perlindungan yang berlaku di Indonesia selama ini.

\section{Sumber Bahan Hukum}

Sumber bahan hukum yang digunakan adalah Undang-Undang Nomor 29 Tahun 2004 tentang Praktik Kedokteran, Undang-Undang Nomor 36 Tahun 2009 tentang Kesehatan, Undang-Undang Nomor 44 Tahun 2009 tentang Rumah Sakit, Peraturan Presiden Nomor 72 Tahun 2012 tentang Sistem Kesehatan Nasional, Peraturan Menteri Kesehatan Nomor 722/Menkes/SK/XII/2002 tentang Pedoman Peraturan Internal Rumah Sakit, Peraturan Menteri Kesehatan Nomor 377/Menkes/ SK/III/2007 tentang Standar Profesi Perekam Medis dan Informasi Kesehatan, Peraturan Menteri Kesehatan Nomor 290/Menkes/PER/III/2008 tentang Persetujuan Tindakan Medik, Putusan Pengadilan No. 221/Pdt.G/2004/PN Tng, dan Putusan Pengadilan No. 90/Pid.B/2011/PN Mdo.

\section{Metode Pengumpulan dan Analisis Data}

Pengumpulan data dilakukan dengan cara penelusuran terhadap isu-isu di media massa, penelusuran buku-buku, jurnal, peraturan hukum, dan putusan pengadilan, yang kemudian dianalis menggunakan metode deskriptif untuk menjawab rumusan masalah. ${ }^{8}$ Langkah yang dilakukan adalah menelusuri aturan hukum, baik undang-undang maupun peraturan menteri kesehatan, kemudian ditelaah dan dianalisis yang berkaitan konsep informed consent dan konsep hak-hak pasien lainnya.

Selain aturan hukum, perlu dilihat konsep

Johnny Ibrahim, 2006, Teori dan Metodologi Penelitian Hukum Normatif, Bayumedia Publishing, Malang, hlm. 295.

Peter Mahmud Marzuki, 2011, Penelitian Hukum, Kencana Prenada Media Group, Jakarta, hlm. 35.

Ibid, hlm. 93.

Penelitian deskriptif adalah suatu penelitian yang dimaksudkan untuk memberikan data yang seteliti mungkin dengan manusia, keadaan atau gejala-gejala lainnya, serta hanya menjelaskan keadaan objek masalahnya tanpa bermaksud mengambil kesimpulan yang berlaku umum. Lihat, Soerjono Soekanto, 1981, Pengantar Penelitian Hukum, UI Press, Jakarta, hlm. 10. 
perlindungan dan konsep pembuktian yang berlaku selama ini dan melihat serta menganalisis kasus yang terjadi, karena konsep hukum adalah perpaduan antara das sollen dan das sein, ketika terjadi perselisihan disitulah ada permasalahan, karena harapan undang-undang tidak sesuai dengan fakta yang terjadi atau sebaliknya. Dari analisis dengan menggunakan 3 (tiga) pendekatan tersebut, maka menuai hasil berupa deskripsi pelaksaan pemenuhan hak pasien dan model perlindungan yang seyogyanya dapat diterapkan.

\section{Hasil Penelitian dan Pembahasan}

\section{Penilaian Hakim Atas Expressed Consent}

\section{Pada Pelaksanaan Informed Consent}

Pada dasarnya, penegakan hukum berisikan tentang: (1) materi hukum (peraturan/perundangundangan); (2) aparatur penegak hukum (hakim, jaksa, polisi, advokat, dan lembaga pemasyarakatan); (3) sarana dan prasarana hukum; dan (4) budaya hukum (legal culture). ${ }^{9}$ Proses penegakan hukum sendiri mendekatkan pada adagium yang berlaku secara umum, yakni bagaikan mata koin yang memiliki 2 (dua) sisi. Bahwa antara instrument dan perangkat hukum harus berkualitas, tidak memprioritaskan pada satu hal saja senada dengan konsep cita hukum (justice). ${ }^{10}$

Proses penegakan hukum sebenarnya bukan terjadi pada tahap aplikasi/pelaksanaan hukum (law enforcement) saja, tetapi bisa dimulai pada tahap formulasi (tahap pembuatan undang-undang). Sementara itu, Satjipto Rahardjo mengatakan penegakan hukum adalah merupakan suatu usaha untuk mewujudkan ide-ide dan konsep-konsep menjadi kenyataan. Penegakan hukum adalah suatu proses untuk mewujudkan keinginan-keinginan hukum menjadi kenyataan. Keinginan-keinginan hukum adalah pikiran-pikiran badan pembuat undang-undang yang dirumuskan dalam peraturanperaturan hukum. ${ }^{11}$ Terkait dengan penegakan hukum dalam penyelesaian perkara pidana sendiri ada ketidakmutlakan terhadap asas legalitas, Nyoman Serikat Putrajaya berpendapat, bahwa:12

Asas legalitas atau principle of legality walupun diakui sebagai dasar asas yang fundamental oleh negara-negara menggunakan hukum pidana sebagai sarana penanggulan kejahatan, namun berlakunya tidak secara mutlak. Dalam arti pembentuk Undang-Undang dapat menyamakan suatu perbuatan yang telah terjadi sebagai tindak pidana dan dapat dipidana asalkan perbuatan tersebut bertentangan dangan hukum tertulis yang dalam hukum pidana internasional disebut prinsip-prinsip hukum umum yang diakui oleh bangsa-bangsa.

Dalam memudahkan pemahaman penilaian hakim atas Expressed Consent, akan diuraikan penjelasan kasus yang telah diputus dengan Putusan Nomor 90/Pid.B/2011/PN Mdo oleh majelis hakim Pengadilan Negeri Manado. Kasus ini termasuk tindak pidana karena kealpaan yang menyebabkan matinya seseorang, yaitu Siska Makatei, yang memenuhi unsur-unsur di dalam Pasal 359 KUHP jo. Pasal 361 KUHP, Pasal 55 ayat (1) ke-1 KUHP. Para Terdakwa adalah Tergugat dari dr. Dewa Ayu Sasiary Prawani (Terdakwa I), dr. Hendry Simanjuntak (Terdakwa II), dan dr. Hendy Siagian (Terdakwa III) dan Penggugat Jaksa Penuntut Umum, pada Pengadilan Negeri Manado Nomor 90/Pid.B/2011/ PN Mdo tanggal 22 September 2011, yang amar lengkapnya sebagai berikut: 1 . Menyatakan Terdakwa I dr. Dewa Ayu Sasiary Prawani, Terdakwa II dr. Hendry Simanjuntak,

\footnotetext{
Sudibyo Saleh, 2004, Komitmen Supremasi Hukum di tengah Kemajuan Masyarakat Indonesia, Makalah yang disampaikan dalam Dialog Nasional Profesional Aparat Penegak Hukum dalam Pelaksanaan di tengah Masyarakat yang Bersih dan Berwibawa, Jakarta, 11 Oktober, hlm. 5-6.

10 Cita hukum adalah keadilan (justice) dalam konteks perkembangan abad 21 telah berubah. Abad nasionaisme modern yang mengutamakan daya nalar hampir tidak pernah memuaskan pikiran manusia tentang arti dan makna keadilan (Belanda: rechtsvaardigheid) di dalam irama gerak hukum dalam masyarakat. Lihat, Satjipto Rahardjo, 2006, Sisi-Sisi lain dari Hukum di Indonesia, Cetakan Kedua, Penerbit Buku Kompas, Jakarta, hlm. 169

11 Satjipto Rahardjo, 2009, Penegakan Hukum, Suatu Tinjauan Sosiologis, Genta Publishing, Yogyakarta, hlm. 24.

12 Nyoman Serikat Putrajaya, 2004, Pemberlakuan Hukum Pidana Secara Retroaktif Sebagai Penyimbang Asas Legalitas dan Asas Keadilan (Suatu Pergeseran Paradigma Dalam Ilmu Hukum Pidana, Pidato Pengukuhan Guru besar, Universitas Diponegoro Semarang, 7 Agustus, hlm. 37 .
} 
dan Terdakwa III dr. Hendy Siagian, tidak terbukti secara sah dan meyakinkan bersalah melakukan tindak pidana dalam dakwaan Kesatu Primair dan Subsidair, dakwaan Kedua, dan dakwaan Ketiga Primair dan Subsidair.

Dakwaan primer yang didakwakan kepada para Terdakwa yaitu melanggar pasal 359 KUHP jo. pasal 361 KUHP jo. pasal 55 ayat (1) ke-1 KUHP yang merupakan pasal pemberatan dari pasal yang didakwakan dalam dakwaan kesatu subsider, yaitu melanggar pasal 359 KUHP jo. Pasal 55 ayat (1) ke-1 KUHP Jis. Dibebaskannya para Terdakwa dari dakwaan kesatu primer yaitu melanggar Pasal 359 KUHP, Pasal 361 KUHP jo. Pasal 55 ayat (1) ke-1 KUHP, maka kepada para Terdakwa haruslah dibebaskan pula dari dakwaan kesatu subsider, yaitu melanggar pasal 359 KUHP jo. Pasal 55 ayat (1) ke-1 KUHP. Membebaskan Terdakwa I, Terdakwa II, dan Terdakwa III oleh karena itu dari semua dakwaan (Vrijspraak) dan Memulihkan hak para Terdakwa dalam kemampuan, kedudukan, dan harkat serta martabatnya.

Selanjutnya pada tingkat kasasi di Mahkamah Agung berdasarkan putusan Nomor 365K/Pid/2012, menyatakan para Terdakwa masing-masing dr. Dewa Ayu Sasiary Prawani (terdakwa I), dr. Hendry Simanjuntak (terdakwa II), dan dr. Hendy Siagian (terdakwa III), terbukti secara sah dan meyakinkan, telah bersalah melakukan tindak pidana sebagaimana dimaksud dalam pasal 359 KUHP jo. pasal 55 ayat (1) ke-1 KUHP. Menjatuhkan hukuman terhadap para terdakwa, masing-masing dr. Dewa Ayu Sasiary Prawani (terdakwa I), dr. Hendry Simanjuntak (terdakwa II), dan dr. Hendy Siagian (terdakwa III), dengan pidana penjara selama 10 (sepuluh) bulan, hal dengan pertimbangan hakim antara lain:

1. Judex Facti salah menerapkan hukum, karena tidak mempertimbangkan dengan benar hal-hal yang relevan secara yuridis, yaitu berdasarkan hasil rekam medis Nomor Nomor 041969 yang telah dibaca oleh saksi ahli dr. Erwin Gidion Kristanto bahwa pada saat korban masuk RSU (Rumah Sakit Umum) Prof. R. D. Kandou Manado, keadaan umum korban adalah lemah dan status penyakit korban adalah berat;

2. Para Terdakwa sebelum melakukan operasi cito secsio sesaria terhadap korban dilakukan, para Terdakwa tanpa menyampaikan kepada pihak keluarga korban tentang kemungkinan yang dapat terjadi terhadap diri korban;

3. Perbuatan para Terdakwa melakukan operasi terhadap korban Siska Makatey yang kemudian terjadi emboli udara yang masuk ke dalam bilik kanan jantung yang menghambat darah masuk ke paru-paru kemudian terjadi kegagalan fungsi paru dan selanjutnya mengakibatkan kegagalan fungsi jantung;

4. Perbuatan para Terdakwa mempunyai hubungan kausal dengan meninggalnya korban Siska Makatey sesuai Surat Keterangan dari Rumah Sakit Umum Prof. Dr. R. D. Kandou Manado Nomor 61/VER/IKF/FK/K/VI/2010, tanggal 26 April 2010.

Berdasarkan hasil upaya hukum Peninjuan Kembali ke Mahkamah Agung pada putusan PK Nomor 79 PK/PID/2013, dr. Ayu, dkk dibebaskan dari dakwaan oleh majelis Peninjauan Kembali (PK) yang diketuai oleh Mohammad Saleh dengan beranggotakan Prof. Surya Jaya, Syarifuddin, Margono, Maruap Pasaribu. Meskipun demikian, putusan ini tidak diambil dengan suara bulat. Salah satu anggota majelis, Prof. Surya Jaya mengajukan dissenting opinion (pendapat berbeda). Ridwan mengutip pertimbangan putusan bahwa pemohon PK (dokter Ayu, dkk) tidak menyalahi Standar Operasional Prosedur (SOP) dalam menangani operasi cieto cisaria. Majelis PK mengganggap pertimbangan judex factie (pengadilan negeri) sudah tepat dan benar. "Memerintahkan agar para terpidana dikeluarkan dari lembaga pemasyarakatan dan memulihkan nama baik para terpidana dalam amar putusan. Putusan yang dijatuhkan terhadap dr. Ayu, dkk, baik pada tingkat pertama, banding, dan kasasi adalah melakukan kealpaan.

Perbuatan para Terdakwa sebagaimana diatur dan diancam pidana dalam Pasal 76 Undang- 
Undang RI Nomor 29 Tahun 2004 tentang Praktik Kedokteran jo. Pasal 55 ayat (1) ke-1 KUHP, yakni memenuhi unsur-unsur antar lain:

a. Unsur Barang Siapa

Pengertian barang siapa adalah kata ganti orang, yang lazimnya dipergunakan dalam setiap perumusan pasal-pasal tindak pidana dari peraturan perundang-undangan yang bersangkutan atau dengan kata lain dapat diartikan pula sebagai subjek pelaku delik. Subyek delik dalam kasus ini adalah Terdakwa I dr. Dewa Ayu Sasiary Prawani, Terdakwa II dr. Hendry Simanjuntak, dan Terdakwa III dr. Hendry Siagian, dimana identitas para Terdakwa disebut dengan Terdakwa I, Terdakwa II, dan Terdakwa III.

b. Unsur karena kesalahannya menyebabkan matinya orang lain

Pada saat sebelum operasi cito secsio sesaria terhadap korban dilakukan, para Terdakwa tidak pernah menyampaikan kepada pihak keluarga tentang kemungkinankemungkinan terburuk, termasuk kematian, yang dapat terjadi terhadap diri korban jika operasi cito secsio sesaria tersebut dilakukan. Para Terdakwa sebagai dokter yang melaksanakan operasi cito secsio sesaria terhadap diri korban juga tidak melakukan pemeriksaan penunjang, seperti pemeriksaan jantung, fotorontgen dada, dan pemeriksaan penunjang lainnya adalah merupakan kelalaian dari para Terdakwa. Tindakan medis yang dilakukan oleh dr. Ayu ada beberapa hal yang termasuk dalam kelalaian, yaitu:

1. Julia dinyatakan dalam keadaan darurat pada pukul 18.30 WITA, padahal seharusnya dinyatakan darurat sejak ia masuk rumah sakit pada pagi hari.

2. Sebagian tindakan medis Ayu dan rekan-rekannya tidak dimasukkan ke rekam medis.

3. Ayu tidak mengetahui pemasangan infus dan jenis obat infus yang diberikan kepada korban.

4. Meski Ayu menugasi Hendy memberi tahu rencana tindakan kepada pasien dan keluarganya, Hendy tidak melakukannya. Ia malah menyerahkan lembar persetujuan tindakan yang telah ditandatangani Julia kepada Ayu, tapi ternyata tanda tangan di dalamnya palsu.

5. Tidak ada koordinasi yang baik di dalam tim Ayu saat melakukan tindakan medis.

6. Tidak ada persiapan jika korban mendadak mengalami keadaan darurat.

Beberapa putusan pengadilan di atas terkait dengan informed consent yang berimplikasi pada malpraktik kedokteran pada tindakan medis, dimana posisi pasien dalam kondisi yang sangat lemah, tidak berdaya, dan tidak mendapat perlindungan hukum. UU Kesehatan, UU Tenaga Kesehatan, UU Praktik Kedokteran, dan UU tentang Rumah Sakit, jelas menempatkan pasien pada obyek yang memperlukan perawatan, sehingga tidak ada celah hukum untuk menuntut haknya, terkait kesalahan prosedur, cacat, dan cacat permanen, bahkan kematian akibat tindakan medis. Informed consent yang menjadi dasar persetujuan di sini dalam tindakan kedokteran telah diabaikan.

Sanksi yang terdapat pada peraturan perundang-undangan di bidang kesehatan sendiri terkesan tidak tegas, karena hakim lebih merujuk pada ketentuan pada KUHP pasal kelalaian. Seharusnya hakim dapat merujuk pada pengaturan informed consent pada Peraturan Menteri Kesehatan Nomor 290/MENKES/PER/ III/2008 tentang Persetujuan Tindakan Kedokteran. Terlebih peraturan ini merupakan pelaksanaan dari Pasal 45 Undang-Undang Nomor 29 Tahun 2004 tentang Praktik Kedokteran. Semua pihak yang terlibat dalam dugaan malpraktik kedokteran selalu mengabaikan ketentuan-ketentuan dalam pasal ini. Putusan Peninjauan Kembali Mahkamah Agung Republik Indonesia Nomor: 76 PK/ 
Pid/2013, atas nama Terdakwa Dewa Ayu Sasiary Prawani, Hendry Simanjuntak, dan Hendy Siagian, Mahkamah Agung menyatakan dan menjatuhkan putusan bahwa para Terpidana tidak terbukti secara sah dan menyakinkan bersalah melakukan tindak pidana yang didakwakan, oleh karena itu majelis hakim tingkat PK membatalkan Putusan Mahkamah Agung Nomor: $365 \mathrm{~K} / \mathrm{Pid} / 2012$ tanggal 18 September 2012 yang membatalkan putusan Pengadilan Negeri Manado Nomor: 90/Pid.B/2011/ PN Mdo.

Kasus di atas terlihat bahwa aspek informed consent diabaikan oleh para dokter, karena dapat dibuktikan bahwa tanda tangan korban, yang berada dalam surat persetujuan tindakan khusus dan persetujuan pembedahan dan anastesi yang diserahkan oleh dr. Hendy Siagian untuk ditandatangani oleh korban, berbeda dengan tanda tangan korban yang berada di dalam Kartu Tanda Penduduk(KTP) dan Kartu Askes. Setelah kemudian dilakukan pemeriksaan oleh Laboratorium Forensik Cabang Makasar dan berdasarkan hasil pemeriksaan Laboratoris Kriminalistik pada tanggal 09 Juni 2010 NO.LAB: 509/DTF/2011, Laboratorium Kriminalistik menyatakan bahwa tanda tangan atas nama Siska Makatey alias Julia Fransiska Makatey pada dokumen tersebut adalah tanda tangan karangan atau dikenal dengan "Spurious Signature”.

Pembuktian tersebut menandakan bahwa aspek informed consent dan adanya transaksi terapeutik merupakan dasar seorang dokter untuk melakukan tindakan medis. Diabaikannya aspek informed consent dan transaksi terapeutik, maka dalam ajaran hukum pidana hal tersebut termasuk dalam kelalaian pada tindakan medis. Agar seorang dokter yang melakukan suatu tindakan medis tanpa didahului oleh aspek informed consent dan transaksi teraupetik dapat dipidana, pihak yang berwenang harus dapat membuktikannya. Tanpa adanya aspek informed consent dalam suatu tindakan medis, maka hal tersebut dapat masuk unsur kesalahan sesuai dengan Pasal 359 KUHP.

Secara yuridis, dasar mengikat dari Peraturan Menteri Kesehatan Nomor 290/MENKES/PER/ III/2008 tentang Persetujuan Tindakan Kedokteran tidak memberikan sanksi dalam hal pengabaian terhadap informed consent yang telah merugikan pasien. Tentu hal ini menciderai pelaksanaan hak asasi kesehatan yang sudah diamanatkan oleh Undang-Undang Dasar. Dalam tindakan medis, seharusnya pasien dan dokter/tenaga kesehatan dalam posisi yang seimbang, yakni hubungan hukum antara pasien dan dokter/tenaga kesehatan merupakan kontraktual yang satu sama lain sama dalam hukum. Ini harus dipahami dalam tindakan medis, supaya tindakan yang diduga malprakatik kedokteran terhadap pasien dapat dihindari. Perlu diingat bahwa persetujuan dalam tindakan kedokteran yang mengandung risiko tinggi harus memperoleh persetujuan tertulis yang ditandatangani oleh pihak yang memberikan persetujuan. Tindakan kedokteran yang tidak masuk risiko dapat diberikan dengan persetujuan lisan. Essensi persetujuan dari informed consent dalam tindakan medis adalah persetujuan antara pasien dan dokter/tenaga kesehatan. Senada dengan J Guwandi, bahwa informasi yang berkaitan dengan risiko dalam pengungkapannya mempertimbangkan sifat dari risiko, kepentingan dari risiko, kemungkinan timbulnya risiko, dan segera tidaknya akan timbul risiko itu. ${ }^{13}$

Oleh karena itu, informed consent dengan melihat fakta-fakta dari putusan pengadilan yang diduga malpraktik yang dilakukan kedokteran dapat diminimilisir, dengan menempatkan pengaturan informed consent hak bagi setiap orang. Dengan menempatkan informed consent sebagai hak yang melekat pada diri seseorang, baik pasien, dokter/ tenaga kesehatan, maka akan terjaga pola hubungan

13 J Guwandi, 1994, Tanya-Jawab Persetujuan Tindakan Medik (Informed Consent), Balai Penerbit Fakultas kedokteran Universitas Indonesia, Jakarta, hlm. 23 
yang seimbang, sejajar satu sama lain. Penghargaan pada hak-hak pasien dengan menempatkan hak informed consent pada hak pasien yang harus dihormati, dihargai, dan diberikan sanksi yang tegas apabila tidak dilakukan. Pada dasarnya hakim dalam menilai perkara bersifat absolute, karena hakim harus menilai expressed consent sebagai syarat tindakan yang akan dilakukan oleh dokter atau tenaga kesehatan, kecuali pasien dalam keadaan emergency maka persetujuan pasien tidak dibutuhkan lagi. Hal ini mengingat bahwa keselamatan pasien adalah hukum tertinggi sesuai dengan asasnya yakni agroti salus lex suprema. ${ }^{14}$

\section{Model Perlindungan Dan Pemenuhan Hak Pasien (Informed Consent) Di Indonesia}

Dalam rangka membangun konsep berupa model penegakan hukum terkait informed consent, maka terlebih dahulu perlu diuraikan Putusan Nomor 46 K/Pdt/2006. Kasus malpraktik Rumah Sakit Siloam Gleneagles pada sunat tanpa persetujuan dari pasien. Penggugat adalah Abraham Lodewyk Tahapary, bertempat tinggal di Perumahan Binong Permai Blok EE 11/13, Curug Tangerang, dan Tergugat adalah PT Siloam Healthcare, tbk cq. Rumah Sakit Siloam Gleneagles Karawaci, beralamat di Jalan Siloam Nomor 6 Lippo Karawaci, Tangerang yang terdiri dari dr. Rudi Hartanto, dr. Nanda Romli, dan dr. Rizal s. Pohan. Pertimbangan sebelum dilakukan pembiusan total, Penggugat memberikan persetujuan secara lisan maupun tertulis dengan menandatangani surat persetujuan yang disodorkan oleh perawat hanya untuk menjalani operasi pencabutan pen di atas mata kaki kiri yang akan dilakukan oleh Tergugat IV selaku dokter ahli bedah tulang.

Sebelum dilakukan pembiusan total, Penggugat sama sekali tidak pernah membicarakan, tidak pernah meminta, dan tidak pernah memberikan persetujuan baik lisan maupun tertulis untuk dilakukan tindakan operasi circumsisi (operasi sunat terhadap penis) terhadap Penggugat di hadapan
Tergugat I oleh Tergugat II, Tergugat III, dan Tergugat IV. Dalam hal ini, Penggugat sebagai orang Ambon beragama Kristen Protestan sama sekali tidak pernah mempunyai maksud dan rencana untuk disunat oleh siapapun, dimanapun, dan kapanpun. Setelah Penggugat memberikan persetujuan lisan maupun tertulis dengan menandatangani surat persetujuan (informed consent) dimaksud butir 3 di atas, selanjutnya Tergugat III selaku dokter anestesi melakukan pembiusan total terhadap Penggugat, sehingga akibat pembiusan total tersebut Penggugat kehilangan kesadaran dan tidak ingat apa-apa lagi.

Bahwa ketika Penggugat dalam keadaan tidak sadar dan tidak ingat apa-apa akibat pembiusan total yang tersebut pada butir 5 di atas, selain dilakukan operasi pencabutan pen di mata kaki yang dilakukan oleh Tergugat IV selaku dokter ahli bedah tulang, ternyata Tergugat II telah melakukan tindakan invasif (tindakan medik yang langsung dapat mempengaruhi keutuhan jaringan tubuh) secara illegal terhadap Penggugat, yaitu melakukan tindakan operasi circumsisi (operasi sunat terhadap penis) terhadap penis Penggugat tanpa memberikan penjelasan terlebih dahulu kepada Penggugat, dan tanpa ada persetujuan baik tertulis maupun lisan dari Penggugat kepada para Tergugat, baik sebelum, maupun setelah operasi circumsisi tersebut. Tindakan Tergugat II tersebut diketahui dan disetujui oleh Tergugat I, Tergugat III, dan Tergugat IV.

Tindakan operasi circumsisi tanpa persetujuan dari Penggugat yang dilakukan oleh Tergugat I oleh Tergugat II, yang diketahui dan disetujui oleh Tergugat I, Tergugat III, dan Tergugat IV telah terbukti dan diakui oleh Tergugat I dalam Surat Nomor 093/RSSG/CS/XII/98, tanggal 8 Desember 1998, yang pada intinya Tergugat I mengakui dan meminta maaf karena telah melakukan tindakan operasi circumsisi tanpa persetujuan dari Penggugat. Bahwa tindakan operasi circumsisi tanpa persetujuan dari Penggugat tersebut di atas telah melanggar

14 Alexandra Indriyanti Dewi, 2008, Etika dan Hukum Kesehatan, Pustaka Book Publishing, Yogyakarta, hlm. 167. 
Pasal 2 ayat (1), (2) dan (3) Peraturan Menteri Kesehatan Rl Nomor 585/Men.Kes/Per/IX/1989 tentang Persetujuan Tindakan Medik (selanjutnya ditulis Permenkes No. 585/1989).

Persetujuan tersebut berdasarkan Pasal 8 ayat (1) Permenkes No. 585/1989 harus diberikan oleh pasien dewasa (Penggugat) dalam keadaan sadar dan sehat mental. Tindakan operasi circumsisi tanpa persetujuan dari Penggugat juga melanggar Kode Etik Rumah Sakit Indonesia (KODERSI) Pasal 2, Pasal 9, Pasal 10, dan Pasal 11 Bab III Kewajiban Rumah Sakit Terhadap Pasien. Selain melakukan tindakan operasi circumsisi yang dilakukan secara illegal oleh para Tergugat tanpa persetujuan Penggugat, ternyata Tergugat I juga tidak bersedia memberikan salinan rekam medis/medical record Penggugat yang diminta oleh dan menjadi hak Penggugat berdasarkan Pasal 10 ayat (2) dan Pasal 14 Peraturan Menteri Kesehatan R1 Nomor 749A/Men.Kes/Per/XII/1989 tentang rekam medis/medical record (selanjutnya ditulis Permenkes No. 749A/1989), yang mana rekam medis/medical record tersebut diperlukan Penggugat untuk kepentingan dasar pemeliharaan kesehatan dan pengobatan Penggugat, serta untuk bahan pembuktian dalam perkara hukum.

Pasal 55 Undang-Undang Nomor 32 Tahun 1992 tentang Kesehatan (selanjutnya ditulis UU No. 32/1992) mengatur bahwa "Setiap orang berhak atas ganti rugi akibat kesalahan atau kelalaian yang dilakukan tenaga kesehatan." dan Penjelasan Pasal 55 UU No. 32/1992 dengan tegas dan jelas mengatur bahwa "Pemberian hak atas ganti rugi merupakan suatu upaya untuk memberikan pertindungan bagi setiap orang atas suatu akibat yang timbul, baik fisik maupun non fisik, karena kesalahan atau kelalaian tenaga kesehatan". Perlindungan ini sangat penting karena akibat kelalaian atau kesalahan itu mungkin dapat menyebabkan kematian atau menimbulkan cacat yang permanen. ${ }^{15}$

Tindakan para Tergugat yang telah melakukan operasi circumsisi tanpa persetujuan Penggugat dan tidak bersedia memberikan salinan Rekam medis Penggugat yang menjadi hak Penggugat, adalah merupakan perbuatan melawan hukum sebagaimana dimaksud dalam Pasal 1365 BW yang telah menimbulkan kerugian yang sangat besar bagi Penggugat baik materiil/fisik maupun immateriil/ non-fisik. Penggugat secara pribadi maupun melalui kuasa hukum sebelumnya, telah berkalikali meminta pertanggungjawaban dan menuntut ganti rugi, namun tidak ada tanggapan dan tidak ada itikad baik dari para Tergugat, untuk mengganti kerugian kepada Penggugat.

Pengadilan Negeri Tangerang telah mengambil putusan melalui Putusan Nomor 221/Pdt.G/2004/ PN Tng tanggal 3 Maret 2005, yang amarnya sebagai berikut: Dalam Eksepsi, menyatakan Eksepsi Tergugat tidak dapat diterima; dalam pokok perkara (1) Menolak gugatan Penggugat untuk seluruhnya; dan (2) Menghukum Penggugat untuk membayar biaya perkara sebesar Rp 514.000, - (lima ratus empat belas ribu rupiah). Dalam upaya tingkat banding, Penggugat dengan Putusan Pengadilan Negeri tersebut telah dikuatkan oleh Pengadilan Tinggi Banten dengan Putusan Nomor 54/Pdt/2005/PT Banten, tanggal 1 September 2005. Selanjutnya berdasarkan surat kuasa khusus tanggal 16 Maret 2005 diajukan permohonan kasasi secara lisan pada tanggal 26 Oktober 2005 sebagaimana ternyata dari akte permohonan kasasi Nomor 221/ Pdt.G/2004/PN Tng, yang dibuat oleh Panitera Pengadilan Negeri Tangerang, permohonan disertai dengan memori kasasi yang memuat alasan-alasan yang diterima di Kepaniteraan Pengadilan Negeri tersebut pada tanggal 9 November 2005.

Terlihat bahwa sepanjang acara pembuktian, Penggugat tidak dapat membuktikan tentang tindakan pembiusan total ataupun kegagalan pembiusan lokal yang dilakukan oleh Tergugat III terhadap diri Penggugat. Menurut Majelis, penilaian terhadap perkara ini yang menjadi titik

15 Kerugian fisik adalah hilangnya atau tidak berfungsinya seluruh atau sebagian organ tubuh, sedangkan kerugian non fisik berkaitan dengan martabat seseorang. 
tolak permasalahannya adalah tentang pembuktian tindakan pembiusan tersebut baru kemudian akan ada penilaian kebenaran ada tidaknya izin yang diberikan Penggugat kepada Tergugat III. Berdasarkan bukti-bukti sangkalan dari Tergugat, pada faktanya Penggugat tidak berhasil membuktikan gugatannya, dalam hal mana yang dilakukan Tergugat III bukanlah pembiusan total akan tetapi pembiusan lokal.

Judex Facti sama sekali tidak mempertimbangkan fakta bahwa Pemohon Kasasi selama menjalani tindakan medis, pada saat dibius oleh Termohon Kasasi III maupun pada saat berada di ruang operasi, adalah seorang pasien dalam keadaan tidak berdaya seorang diri yang mempercayakan dirinya ditangan para Termohon Kasasi sepenuhnya. Seluruh pihak yang ada, selain Pemohon Kasasi, pada saat itu hanyalah para Termohon Kasasi dan perawat-perawat yang bekerja untuk Termohon Kasasi I, sehingga seluruh keterangan dari para Termohon Kasasi dan dokumen-dokumen yang ada dibuat secara sepihak oleh para Termohon Kasasi.

Fakta hukum yang terjadi adalah Pemohon Kasasi dalam keadaan tidak sadarkan diri, bahkan sebelum masuk ke ruangan operasi, sehingga tidaklah mungkin Pemohon Kasasi dapat mengetahui apakah ada di antara para Termohon Kasasi yang benar-benar telah menjelaskan akan melakukan tindakan circumsisi, apalagi sampai memberikan persetujuan atas tindakan circumsisi yang akan dilakukan para Termohon Kasasi. Maka sangat tidak adil dan tidak mungkin sehingga terbukti keliru pertimbangan hukum Judex Facti yang pada intinya berpendapat Pemohon Kasasi yang harus membuktikan Pemohon Kasasi telah dibius total. ${ }^{16}$ Sebaliknya, para Termohon Kasasilah yang seharusnya membuktikan bahwa Pemohon Kasasi dalam keadaan sadar dan telah mengerti sepenuhnya akan dilakukan tindakan circumsisi. Oleh karena itu, seharusnya para Termohon Kasasi membuktikan dalilnya dengan memberikan Rekam Medis Pemohon Kasasi yang diminta oleh dan menjadi hak Pemohon Kasasi, sehingga melanggar Pasal 10 ayat (2) dan Pasal 14 Permenkes No. 749A/1989 tentang Rekam Medis. ${ }^{17}$

Putusan Mahkamah Agung tanggal 15 Maret 1972 Nomor 549K/Sip/1971, menyebutkan bahwa "Berdasarkan yurisprudensi, Hakim bebas untuk memberikan beban pembuktian, lebih tepat jika pembuktian dibebankan kepada yang lebih mampu untuk membuktikannya”. Hal ini sesuai dengan teori yang dikemukakan oleh R. Subekti bahwa "Hendaknya Hakim dalam membagi beban pembuktian, dalam tingkat terakhir menitikberatkan pada pertimbangan keadilan." 18

Tetapi harus tetap dijaga jangan sampai Hakim itu memerintahkan pembuktian sesuatu hal yang negatif. Apabila Hakim secara mutlak mengikuti aturan tersebut yaitu bahwa yang mendalilkan yang dibebani pembuktian maka penulis berpendapat bahwa hal itu akan menimbulkan beban pembuktian yang berat sebelah baginya. Dengan demikian, pada akhirnya tidak akan mencapai tujuan atau hasil yang baik, karena pada satu pihak disuruh membuktikan sesuatu keadaan yang negatif'. ${ }^{19}$

\footnotetext{
16 Sirkumsisi dalam Bahasa Indonesia disebut sunat. Bahasa Arab disebut Khitanul-Unstya atau khitanul-banat atau khafidlul-banat yang ketiganya berarti sama yakni sunat pada perempuan. Lihat, Akhmad Rifai, 2001, Wacana Sirkumsisi pada Perempuan, Jurnal Populasi, 12 (1) ISSN: 0853-2062, hlm. 57.

17 Rekam Medis adalah berkas yang berisi catatan dan dokumen tentang identitas pasien, pemeriksaan, pengobatan, tindakan, dan pelayanan lain kepada pasien pada fasilitas pelayanan kesehatan. Rekam medis bentuknya ada 2 (dua) macam, yakni rekam medis konvensional dan rekam medis elektronik. Rekam medis konvensional maksimal dapat dikategorikan sebagai akta di bawah tangan. Akta demikian hanya mempunyai dua jenis kekuatan pembuktian, yaitu kekuatan pembuktian formal dan materiil. Rekam medis elektronik, dikarenakan tidak berbentuk tulisan asli, termasuk berkaitan dengan keaslian pembubuhan identitas nama, waktu dan tanda tangan elektronik, maka rekam medis ini tidak dapat dikategorikan ke dalam bentuk alat bukti tertulis atau surat. Dengan demikian, rekam medis elektronik tidak mempunyai kekuatan pembuktian eksternal, formal maupun materiil. Lihat, Nabil Atta Samandari, 2016, Kekuatan Pembuktian Rekam Medis Konvensional dan Elektronik, SOEPRA Jurnal Hukum Kesehatan, Program Magister Hukum Kesehatan Universitas Katoik Soegijapranata Semarang, e-ISSN 2548-818X Vol. 2 No. 2, hlm. 159-161

18 R. Subekti, 2001, Hukum Pembuktian, Cetakan 13, Pradnya Paramita, Jakarta, hlm. 16.

19 Teguh Samudra, 1992, Hukum Pembuktian dalam Acara Perdata, cetakan I, Penerbit Alumni, Bandung, hlm. 23.
} 
Pembaharuan Hukum Perdata mengatakan bahwa hakim yang insaf akan arti kedudukannya tidak akan lupa bahwa dalam membagi-bagi beban pembuktian, ia harus bertindak jujur dan sportif, tidak akan membebankan kepada suatu pihak untuk membuktikan hal yang tidak dapat dibuktikan. ${ }^{20}$ Maka akan menjadi keliru dan bertentangan dengan hukum pertimbangan Judex Facti yang menyatakan Pemohon Kasasi tidak dapat membuktikan tentang adanya tindakan pembiusan total terhadap diri Pemohon Kasasi, karena seharusnya para Termohon Kasasi yang membuktikan sebaliknya dengan menyerahkan rekam medis/medical record Pemohon Kasasi, hal mana tidak dilakukan para Termohon Kasasi. Demikian pula mengenai pemberian ijin untuk melakukan tindakan circumsisi yang tidak pernah dilakukan oleh Pemohon Kasasi, sehingga apa yang terjadi setelah Pemohon Kasasi dibius adalah diluar pengetahuan dan kesadaran Pemohon Kasasi. ${ }^{21}$

Judex Facti telah keliru dalam menerapkan hukum dan melanggar peraturan-peraturan hukum yang berlaku (schending van het recht) dengan membuat pertimbangan "Bahwa tidak bersedianya Tergugat Imemberikan salinan rekam medis/medical record kepada Penggugat, menurut hemat Majelis diberi atau tidak diberinya salinan rekaman medis tidak pula menyebabkan Tergugat I ada atau tidak melakukan perbuatan melawan hukum sehubungan dengan keberatan Penggugat terhadap tindakan rekam medis/medical record tersebut"; "Tindakan circumsisi adalah tindakan medis, sedangkan tidak diberinya salinan rekaman medis adalah tindakan administrasi karenanya keberatan ataupun permasalahan tersebut bukan suatu perbuatan yang berkualifikasi sebagai perbuatan melawan hukum dalam arti keperdataan"; Pertimbangan Judex Facti telah melanggar hukum karena Pasal 10 ayat (2) Permenkes No. 749A/1989 tentang rekam medis mengatur secara tegas bahwa "Isi rekam medis milik pasien". ${ }^{22}$

Ternyata Termohon Kasasi I tidak bersedia memberikan salinan rekam medis/medical record Pemohon Kasasi yang diminta oleh dan menjadi hak Pemohon Kasasi berdasarkan dan Pasal 14 Permenkes No. 749A/1989. Oleh karena itu, tidak berlebihan kiranya apabila Pemohon Kasasi berpendapat bahwa penolakan para Termohon Kasasi untuk memberikan salinan rekam medis/ medical record adalah untuk memyembunyikan fakta yang sebenarnya mengingat rekam medis/ medical record berisikan seluruh catatan dan dokumen yang antara lain tentang pemeriksaan, pengobatan, tindakan, dan pelayanan lain kepada Pemohon Kasasi selama mendapat pelayanan kesehatan dari Para Termohon Kasasi, yang tidak dapat/dilarang untuk dihapus, sebagaimana diatur Pasal 6 Permenkes No. 749A/1989, sebagai berikut:

(1) Pembetulan kesalahan catatan dilakukan pada tulisan yang salah dan diberi paraf oleh petugas yang bersangkutan;

(2) Penghapusan tulisan dengan cara apapun tidak diperbolehkan; Maka terbukti keliru pertimbangan Judex Facti yang menyebutkan tidak diberinya salinan rekaman medis adalah tindakan administrasi karenanya keberatan ataupun permasalahan tersebut bukan suatu

\footnotetext{
Ibid.

21 Pertimbangan Judex Facti seluruhnya hanya berdasar atas keterangan dan dokumen yang dibuat sepihak oleh Pemohon Kasasi tanpa disertai rekam medis/medical record Pemohon Kasasi. Hal mana melanggar ketentuan Pasal 2 ayat (3) dan (4) Peraturan Menteri Kesehatan R1 Nomor 585/Men.Kes/Per/IX/1989 tentang Persetujuan medik yang mengatur bahwa: ayat (3) Persetujuan sebagaimana dimaksud ayat (1) diberikan setelah pasien mendapat informasi yang adekuat tentang perlunya tindakan medik yang bersangkutan serta risiko yang dapat ditimbulkannya; ayat (4) Cara penyampaian tatist informasi harus disesuaikan dengan tingkat tatistic serta kondisi dan situasi pasien; Lebih tegas lagi Pasal 8 ayat (1) mengatur bahwa persetujuan diberikan oleh pasien dewasa yang berada dalam keadaan sadar dan sehat mental. Telah dibuktikan bahwa sampai Pemohon Kasasi dibius oleh Temohon Kasasi III, Pemohon Kasasi sama sekali tidak pernah membicarakan, tidak pernah mempertanyakan, tidak pernah meminta dilakukan tindakan operasi circumsisi (operasi sunat) terhadap penis Pemohon Kasasi.

22 Pasal 14 Peraturan Menteri Kesehatan Rl Nomor 749A/Men.Kes/ Per/XII/1989, menentukan: “"Rekam medis dapat dipakai sebagai: a. Dasar pemeliharaan kesehatan dan pengobatan pasien; b. Bahan pembuktian dalam perkara hukum;, c. Bahan untuk keperluan penelitian dan pendidikantatistic; dan d. Dasar pembayaran biaya pelayanan kesehatan; Bahan untuk menyiapkan statistiktatistic kesehatan.
} 
perbuatan yang berkualifikasi sebagai perbuatan melawan hukum dalam arti keperdataan, karena jelas diatur dalam ketentuan di atas bahwa rekam medis merupakan dokumen yang sangat penting untuk kepentingan dasar pemeliharaan kesehatan dan pengobatan Pemohon Kasasi, serta untuk bahan pembuktian dalam perkara hukum;

Kesalahan atau kelalaian Para Termohon Kasasi tegas-tegas merupakan pelanggaran hukum, yaitu:

a. Pemohon Kasasi sebelumnya tidak pernah mendapatkan penjelasan dan informasi dari para Termohon Kasasi sehubungan tindakan circumsisi yang melanggar Pasal 2 ayat (3) dan (4) Permenkes No. 585/1989;

b. Pemohon Kasasi tidak pernah memberikan persetujuan atau ijin dalam bentuk apapun dan kepada siapapun untuk dilakukan tindakan circumsisi terhadap Pemohon Kasasi yang melanggar Pasal 2 ayat (1) dan (2) Permenkes No. 585/1989;

c. Sampai Pemohon Kasasi disuntik obat bius, Pemohon Kasasi tidak pernah diberi penjelasan dan juga memberikan persetujuan untuk tindakan circumsisi, hal mana telah diakui para Termohon Kasasi. Seandainya benar quod non, dalil para Termohon Kasasi bahwa telah ada penjelasan dan persetujuan Pemohon Kasasi sebelum dilakukan tindakan circumsisi, penjelasan dan persetujuan untuk tindakan circumsisi, diberikan dalam kondisi di bawah pengaruh obat bius atau tidak sadar, melanggar Pasal 8 ayat (1) Permenkes No. 585/1989;

d. Dokter yang melakukan tindakan medis operasi/bedah (Termohon Kasasi II) sama sekali tidak pernah memberikan penjelasan atau informasi, sementara diatur bahwa informasi harus diberikan oleh dokter yang akan melakukan operasi tersebut melanggar Pasal 6 ayat (1) Permenkes No. 585/1989;

e. Termohon Kasasi III mengetahui tidak ada persetujuan Pemohon Kasasi tetapi tetap membiarkan Termohon Kasasi II melakukan circumsisi terhadap Pemohon Kasasi yang melanggar Pasal 12 ayat (1) Permenkes No. 585/1989;

f. Termohon Kasasi I juga tidak bersedia memberikan salinan rekam medis/ medical record Pemohon Kasasi yang diminta oleh dan menjadi hak Pemohon Kasasi dan dapat membuktikan perbuatan melawan hukum dilakukannya tindakan circumsisi tanpa ijin melanggar Pasal 10 ayat (2) dan Pasal 14 Permenkes No. 749A/1989.

Menjadi terang dan jelas bahwa Pengadilan Tinggi telah keliru dengan mengambil alih pertimbangan Pengadilan Negeri yang melanggar hukum yang dan oleh karena itu permohonan kasasi Pemohon Kasasi tentang hal tersebut dianggap cukup beralasan untuk dapat dikabulkan. Sehingga putusan Pengadilan Tinggi Banten, Tanggal 1 September 2005 Nomor 54/Pdt/2005/PT Banten dan Putusan Pengadilan Negeri Tangerang Tanggal 3 Maret 2005 Nomor 221/PDT.G/2004/ PN Tng harus dibatalkan. Terlihat bahwa hakim dalam melaksanakan tugasnya menerapkan Pasal 66 KUHAP, yakni tersangka atau terdakwa tidak dibebani kewajiban pembuktian. Beberapa teori pembuktian yang berlaku yakni teori positif, teori conviction intime, teori conviction rasionee, dan teori negatif. Teori-teori tersebut dijelaskan oleh Andi Hamzah sebagai berikut: ${ }^{23}$

1. Sistem atau Teori Pembuktian Berdasarkan Undang-Undang Secara Positif (Positive Wettelijk Bewijstheorie) menitikberatkan pembuktian pada alat bukti yang ada pada ketentuan undang-undang saja tanpa menggunakan keyakinan hakim. Sistem atau teori ini sering disebut sebagai teori pembuk-

23 Andi Hamzah, 2015, Hukum Acara Pidana Indonesia, Sinar Grafika, Jakarta, hlm. 251-257. 
tian formal (formele bewijstheorie).

2. Sistem atau Teori Pembuktian Berdasarkan Keyakinan Hakim Melulu menitikberatkan pada keyakinan hakim saja tanpa menggunakan alat bukti yang ada pada ketentuan undangundang. Hakim mengambil keputusan berdasarkan hati nuraninya, sistem atau teori ini sering disebut conviction intime.

3. Sistem atau Teori Pembuktian Berdasarkan Keyakinan Hakim Atas Alasan yang Logis (laconviction rasionnee) menitikberatkan pada keyakinan hakim berdasarkan pertimbangan dan alasan tertentu yang logis. Putusan hakim dan pertimbangan hakim disertai dengan kesimpulan yang berlandaskan peraturan pembuktian tertentu. Sistem atau Teori ini terbagi dua, yang meliputi Sistem atau Teori Pembuktian Berdasarkan Keyakinan Hakim Atas Alasan yang Logis (laconviction rasionnee) dan Sistem atau Teori pembuktian berdasarkan undang-undang secara negatif (negatief wettelijk bewijstheorie).

4. Sistem atau Teori Pembuktian Berdasarkan Undang-Undang Secara Negatif (negatief wettelijk bewijstheorie) menitikberatkan pada pembuktian berganda (dubbel en grondslag), yakni berdasarkan undang-undang dan keyakinan hakim, yang mana keyakinan hakim tersebut bersumber pada undang-undang.

Dari teori yang ada, seharusnya ada rujukan terkait dengan pembuktian terbalik dalam kasus tindak pidana bidang kesehatan seperti halnya ka- sus tindak pidana korupsi dan tindak pidana pencucian uang. ${ }^{24}$ Tindak pidana bidang kesehatan sarat dengan minim dan susahnya untuk mengumpulkan alat bukti, karena kode etik kedokteran memungkinkan untuk menghendaki proses kode etik dokter diselesaikan di tingkat Majelis Kehormatan Disiplin Kedokteran Indonesia. ${ }^{25}$ Unsur sistem pembuktian ialah alat-alat bukti yang boleh digunakan dan caranya membuktikan serta standar yang harus dipenuhi untuk menyatakan terbukti atau tidaknya mengenai objek apa yang dibuktikan. Hal ini sesuai dengan konsep pembuktian, yaitu merupakan ketentuan-ketentuan yang berisi penggarisan dan pedoman tentang cara-cara yang dibenarkan undangundang, membuktikan kesalahan yang didakwakan kepada terdakwa, dan juga merupakan ketentuan yang mengatur alat-alat bukti yang dibenarkan undang-undang dan yang boleh dipergunakan oleh hakim untuk membuktikan kesalahan yang didakwakan. ${ }^{26}$

Alat-alat buktinya jelas ialah dengan menggunakan alat-alat bukti Pasal 183 ayat (1) KUHAP. Beban pembuktian terbalik tidak dikenal dalam KUHAP, hanya dikenal pada Tindak Pidana Korupsi. ${ }^{27}$ Terlihat adanya kelemahan dalam proses penangan tindak pidana di bidang kesehatan yang seharusnya pembuktian dibebankan kepada tersangka atau terdakwa sebagai bentuk perlindungan hukum kepada korban informed consent di Indonesia.

\section{Kesimpulan}

Berdasarkan hasil penelitian ini, dapat

24 Beban pembuktian terbalik biasa disebut sebagai asas pembalikan beban pembuktian atau pembuktian terbalik (Indonesia) yaitu shifting of burden of proof atau reversal burden of proof (Inggris), omkering van de bewijslast (Belanda), dan onus of proof (Latin) yang diartikan sebagai pembalikan beban pembuktian yang dibebankan kepada terdakwa untuk membuktikan dirinya tidak melakukan tindak pidana. Lihat, Supriyadi Widodo Eddyono, 2011, Pembebanan Pembuktian Terbalik dan Tantangannya, Jurnal Legislasi Indonesia, Vol. 8 No. 2 Juni 2011, hlm. 269.

25 Dokter tersangka pelaku pelanggaran standar profesi (kasus kelalaian medik) dapat diperiksa oleh MKEK, dapat pula diperiksa di pengadilan tanpa adanya keharusan saling berhubungan di antara keduanya. Seseorang yang telah diputus melanggar etik oleh MKEK belum tentu dinyatakan bersalah oleh pengadilan, demikian pula sebaliknya. Lihat, Asep Sukohar dan Novita Carolia, 2016, Peran Majelis Kehormatan Etik Kedokteran Indonesia (MKEK), JK Unila Vol. 1 No. 2 Oktober 2016, hlm. 305.

26 M Yahya Harahap, 1993, Pembahasan Permasalahan dan Penerapan KUHAP Jilid II, Pustaka Kartini, hlm. 793.

27 Eksistensi pembalikan beban pembuktian dari perspektif kebijakan legislasi dikenal dalam tindak pidana korupsi sebagai ketentuan yang bersifat "premium remidium" dan sekaligus mengandung prevensi khusus dalam tindak pidana yang bersifat ekstra ordinary crimes sehingga memerlukan ekstra ordiary enforcement. Lihat, Oliver Stolpe, Meeting the burden of proof in corruption related legal proceedings, unpublished, hlm. 1, dalam Lilik Mulyadi, 2007, Asas Pembalikan Beban Pembuktian Terhadap Tindak Pidana Korupsi Dalam Sistem Hukum Pidana Indonesia Dihubungkan dengan Konvensi Perserikatan Bangsa-bangsa Anti Korupsi, 2003, ringkasan Disertasi, Universitas Padjajaran, Bandung, hlm. 8. 
disimpulkan bahwa: Pertama, pengaruh informed consent dijadikan dasar utama oleh hakim dalam menilai kausalitas suatu perbuatan. Persetujuan dalam tindakan kedokteran yang mengandung risiko tinggi harus memperoleh persetujuan tertulis yang ditandatangani oleh hak yang memberikan persetujuan. Di lain sisi, tindakan medis yang tidak masuk risiko dapat diberikan dengan persetujuan lisan.
Kedua, model perlindungan dan pemenuhan hak pasien pada tingkat penegakan hukum (pengadilan) adalah menerapkan asas pembuktian terbalik terhadap dokter/tenaga medis, karena lebih efektif dan terbuka peluang bagi pasien dalam memperoleh keadilan. Hal ini adalah bagian dari pemenuhan hak terhadap pasien, akan tetapi penerapan asas ini harus seimbang dan bukan merupakan suatu hal yang negatif.

\section{DAFTAR PUSTAKA}

\section{A. Buku}

Dewi, Alexandra Indriyant, 2008, Etika dan Hukum Kesehatan, Pustaka Book Publishing, Yogyakarta.

Guwandi, J., 1994, Tanya-Jawab Persetujuan Tindakan Medik (Informed Consent), Balai Penerbit Fakultas kedokteran Universitas Indonesia, Jakarta.

Hamzah, Andi, 2015, Hukum Acara Pidana Indonesia. Sinar Grafika, Jakarta.

Harahap, M. Yahya, 1993, Pembahasan Permasalahan dan Penerapan KUHAP Jilid II, Pustaka Kartini

Ibrahim, Johnny, 2006, Teori dan Metodologi Penelitian Hukum Normatif, Bayumedia Publishing, Malang.

Marzuki, Peter Mahmud, 2011, Penelitian Hukum, Kencana Prenada Media Group, Jakarta.

Rahardjo, Satjipto, 2006, Sisi-Sisi lain dari Hukum di Indonesia, Cetakan Kedua, Penerbit Buku Kompas, Jakarta.

Rahardjo, Satjipto, 2009, Penegakan Hukum, Suatu Tinjauan Sosiologis, Genta Publishing, Yogyakarta.

Samudra, Teguh, 1992. Hukum Pembuktian dalam Acara Perdata, cetakan I, Penerbit Alumni, Bandung.

Soekanto, Soerjono, 1981. Pengantar Penelitian Hukum, UI Press, Jakarta.

Subekti, R., 2001, Hukum Pembuktian, Cetakan 13, Pradnya Paramita, Jakarta.

\section{B. Artikel Jurnal}

Eddyono, Supriyadi Widodo, "Pembebanan Pembuktian Terbalik dan Tantangannya", Jurnal Legislasi Indonesia, Vol. 8 No. 2, Juni 2011.

Rifai, Akhmad, "Wacana Sirkumsisi pada Perempuan", Jurnal Populasi, Vol. 12, Tahun 2001.

Sukohar, Asep, et al., "Peran Majelis Kehormatan Etik Kedokteran Indonesia (MKEK)", JK Unila, Vol. 1 No. 2, Oktober 2016.

Sumandari, Nabil Atta, 2016, "Kekuatan Pembuktian Rekam Medis Konvensional dan Elektronik", SOEPRA Jurnal Hukum Kesehatan, Program Magister Hukum Kesehatan Universitas Katoik Soegijapranata Semarang, e-ISSN 2548-818X Vol. 2 No. 2.

\section{Tugas Akhir}

Mulyadi, Lilik, 2007, Asas Pembalikan Beban Pembuktian Terhadap Tindak Pidana Korupsi Dalam Sistem Hukum Pidana Indonesia Dihubungkan dengan Konvensi Perserikatan Bangsa-bangsa Anti Korupsi 2003, Disertasi, Universitas Padjajaran, Bandung.

\section{Makalah/Pidato}

Putrajaya, Nyoman Serikat, "Pemberlakuan Hukum Pidana Secara RetroaktifSebagaiPenyimbang Asas Legalitas dan Asas Keadilan (Suatu 
Pergeseran Paradigma Dalam Ilmu Hukum Pidana", Pidato Pengukuhan Guru besar, Universitas Diponegoro Semarang, 7 Agustus.

Saleh, Sudibyo, "Komitmen Supremasi Hukum di tengah Kemajuan Masyarakat Indonesia”, Makalah, Dialog Nasional Profesional Aparat Penegak Hukum dalam Pelaksanaan di Tengah Masyarakat yang Bersih dan Berwibawa, Jakarta, 11 Oktober 2004.

\section{E. Internet}

Alamsyah, Ichsan Emrald, "RS Awal Bros Ternyata tak berikan Resume Medis Bayi RFB", https://www.republika.co.id/berita/nasional/ jabodetabek-nasional/15/12/04/nyu64h349rs-awal-bros-ternyata-tak-berikan-resumemedis-bayi-frb, dikases pada tanggal 16 Juli 2019.

Alwy, Sabir, "Dugaan Pelanggaran Disiplin Terbanyak Akibat Kurangnya Komunikasi Dokter dan Pasien", http://www.depkes.go.id/ article/view/1519/dugaan-pelanggarandisiplin-terbanyak-akibat-kurangnyakomunikasi-dokter-dan-pasien.html, diakses 16 Juli 2019.

Detiknews, "Kronologi Kasus Pasien Anna Marlina versi RS Harapan", https://news.detik.com/ berita/d-2229037/kronologi-kasus-pasienanna-marlina-versi-rs-persahabatan, diakses 16 Juli 2019.

Saputro, Didin, "Kasus Bocah Lumpuh: LPA sebut informed consent sangatlah penting", https://radarkediri.jawapos.com/ read/2018/11/10/102934/kasus-bocahlumpuh-lpa-sebut-informed-consentsangatlah-penting, diakses 16 Juli 2019.

\section{F. Peraturan Perundang-undangan}

Kitab Undang-Undang Hukum Pidana;
Undang-Undang Nomor 8 Tahun 1981 tentang Kitab Undang-Undang Hukum Acara Pidana (Lembaran Negara Republik Indonesia Tahun 1981 Nomor 76, Tambahan Lembaran Negara Republik Indonesia Nomor 3209); Undang-Undang Republik Indonesia Nomor 29 Tahun 2004 tentang Praktik Kedokteran (Lembaran Negara Republik Indonesia Tahun 2004 Nomor 116, Tambahan Lembaran Negara Republik Indonesia Nomor 4431); Undang-Undang Republik Indonesia Nomor 36 Tahun 2009 tentang Kesehatan, (Lembaran Negara Republik Indonesia Tahun 2009 Nomor 144, Tambahan Lembaran Negara Republik Indonesia Nomor 5063);

Undang-Undang Republik Indonesia Nomor 44 Tahun 2009 tentang Rumah Sakit (Lembaran Negara Republik Indonesia Tahun 2009 Nomor 153, Tambahan Lembaran Negara Nomor 5072);

Peraturan Presiden Republik Indonesia Nomor 72 Tahun 2012 tentang Sistem Kesehatan Nasional (Lembaran Negara Republik Indonesia Tahun 2012 Nomor 193);

Keputusan Menteri Kesehatan Republik Indonesia Nomor 722/Menkes/SK/XII/2002 tentang Pedoman Peraturan Internal Rumah Sakit;

Keputusan Menteri Kesehatan Republik Indonesia Nomor 377/Menkes/SK/III/2007 tentang Standar Profesi Perekam Medis dan Informasi Kesehatan;

Keputusan Menteri Kesehatan Republik Indonesia Nomor 290/Men.Kes/PER/III/2008 tentang Persetujuan Tindakan Medik.

\section{G. Putusan Pengadilan}

Putusan Pengadilan Negeri Nomor 221/Pdt.G/2004/ PN Tng.

Putusan Pengadilan Negeri Nomor 90/Pid.B/2011/ PN Mdo. 